\title{
Nationality Thought in Developing Critical Education
}

\author{
Anak Agung Gde Putera Semadi \\ Department of Master of Law Science, Law Faculty, Dwijendra University, \\ Denpasar, Indonesia
}

\begin{abstract}
Critical education has a very strategic role in supporting and accelerating the formation of a civilized democratic society. Its existence is able to change the world, create the culture, carve out the history, engineer the world to be more fair and humane, even to change concepts, ideas, systematics, and strength. Implementation of critical education is based on three dimensions: the pedagogic practical, normative, and cultural ideology dimensions. Critical education process is formulated as a process of cultural dimension. The main function and target of critical education is "self-awareness", or "critical awareness". The concoction of Indonesian nationalism as a reflection of critical education has been clearly being pioneered since revolution era by R.A. Kartini, Budi Utomo, and K. H. Dewantara in the form of the establishment of some schools and the freedom of indigenous children to get the education. More qualified human resources can be cultivated through a critical education.
\end{abstract}

Keywords: Nationality, Critical Education

*Corresponding Author:

E-mail: puterasemadi60@gmail.com (Anak Agung Gde Putera Semadi)

Department of Master of Law Science, Law Faculty, Dwijendra University, Denpasar, Indonesia

\section{INTRODUCTION}

Education has a very strategic and crucial role in supporting and even accelerating civilized democratic society building which become one of the most important characters of Indonesian civil society. It also plays a role both individually and socially, in preparing the nation's children in order to have the ability, skills, ethos, and motivation to participate in the development of civil society actively.

There are two dimensions which usually tend to be thought in discussing about education, they are: (1) pedagogic practical dimension, and (2) normative dimension. According to Surakhmad (1977:
7) in Wija (2009: 1), the first dimension is a technical dimension which involves various strategic, process, and action for developing and functioning education in society optimally to achieve nationally defined goal. The second dimension includes a policy that try to formulate educational values as a foundation in realizing the shared ideals in both micro (family / community) and macro scales (national life).

There is one more strategic dimension which is commonly considered (although it is often being ignored) in any education problematic reality problem discussion except those dimensions above
Journal Homepage:

http://ejournal.undwi.ac.id/index.php/jsds
Copyright @ 2021 Dwijendra University. All right reserved. 
which is called a cultural ideological dimension. This dimension includes a power relations practice aspect, a hidden abbarent view of cultural perceptions, the expansion of global ideology domination (globalization), the illusion as the impact of imagery efforts in education, and even the illusion of an absurd education qualification achievement. Dore (1976) termed this one as a diploma disease.

Actually, education process can be placed as a part of complex cultural and social practice network of society if it is seen from cultural side. Education should not only be limited to learning practices at school (schooling), but also related to life that is commonly referred to a process to culture. It is not excessive if educational process is formulated as a process of cultural dimension, or can be termed as humanization process (human humanity) in an effort to develop critical education. Education process can not be separated from human life in order to create cultural and its heritage (cultural creation and cultural transmission) to the young generation. Therefore, a strong cultural foundation is necessary needed in developing a critical education model.

\section{METHODS}

The form of this culture studies research is designed as a qualitative research with a phenomenological approach which prioritizes it's study on text problems and their context in socioty. This study does not use a hyphothesis. All field data and literature study results which have been classified are studied by using ciritcal social

Journal Homepage:

http://ejournal.undwi.ac.id/index.php/jsds theory from Ben Agger in his book entitled Socio(onto)logy; A Disciplinary Reading (1989). In order to obtain a sharp, logical, and systematic explanation, therefore, the application of desciptive analysis methods is clearly unavoidable. The determination of informant was carried out by using purposive random sampling technique and was developed by the snowball technique. The data source was strengthered by research instruments in the form of participatory observation guidelines, indepth interview guidelines, recordings, and document studies.

\section{RESULT AND DISCUSSION}

\subsection{Pearl of Minds in Nationality}

The ideas of nationalism in the effort to develop a critical education in Indonesia have emerged and resonated in the era of $\mathrm{R}$. A. Kartini, and later followed by Budi Utomo as well as Ki Hajar Dewantara until the reform era.

\subsubsection{R.A. Kartini Nationalist Ideas}

Kartini is a revolutionary and progressive fighter. Her thoughts are brave to break down the old custom and be able to reach what women need for their future. Two successful female schools (in Jepara and Rembang) that she built are extraordinary efforts that make her deserve to be called a hero or the pioneer of women's empowerment. Zulkifli, Chief Editor of Tempo magazine stated that;

"Kartini was not only about kebaya and ceremony. Kartini was the right of woman, the fight of gender equality and also the nationalism of Indonesia in the end 
of $19^{\text {th }}$ century. W.R. Supratman has a point when calling Kartini "a women warrior". A warrior is a defender who does not always win a fight. She is a never give up activist-thinker. Kartini rebels the feudalism, polygamy and custom that confine woman. Shebelieves that by giving more equitable education is the key of improvement". (2017: 8)

According to Kartini, to build a civilized and developed nation, it must be started from the education of women. It is from woman that man first receives his upbringing; the child learns to feel, think, and speak. Mukhrizal cites Kartini's view in her letter which is addressed to her pen pal in Holland. In that letter Kartini states;

"Educate our women, our girls. Teach and educate their mental and mind. Make them to be competent and intelligent women, make them as good educators for future generations. The civilization of a nation is only a matter of time if there are mothers who are competent and clever. It is increasingly clear for me that it does not mean that the early education is having no meaning to all life. How mothers of the earth are able to educate their son, if they themselves are uneducated ... "(2016: 190)

In her another letter to M.C.E. Ovink Soer and Mrs. Abendanon, Kartini stated;

"... Education is not solely based on the intelligence of a brain, but also with a genuine attention to the moral creating as well. It must become a concern in all teaching ..."

"... If we want to advance the civilization, then the intellect of mind and the growth of character must be equally developed ..."

"... I often hear people say that the kindness will come by itself, if the mind has been intelligent then education would be fine and refined; But when I have an eye for it, I think that it is really disappointed to know when intelligent behavior, language and mind can not forever be guarantee for them to have good life and character..."

Kartini efforts to develop an education will never be stopped. She considers that (psychomotor) skill is also important to be given to children as knowledge that they can bring to social life as the one which has been tought by her such as; sewing, batik making and etc. Kartini interprets education widely. She believes that education can be delivered anywhere and by anyone. It is not only can be given at school, but it is definitely important to give it to our children starts from their family environment. This is where moral education becomes a very valuable thing for them. Curriculum preparation which contains some materials of brain education (cognitive), character creating (affective) and skill education (psychomotor) is one way that can be done to achieve the goal of education. Therefore, teacher has a very important role as the central figure in Education. A teacher is
Journal Homepage:

http://ejournal.undwi.ac.id/index.php/jsds
Copyright (C) 2021 Dwijendra University. All right reserved. 
becoming an intellectual and moral leader. A teacher should open a dialogical forum to accommodate learners' ideas and stimulate their critical power. Another very important feature of Kartini's historic nationalist thinking until nowadays is the realization of a gender-sensitive education system and learning environment.

\subsubsection{Budi Utomo Nationality Thought}

Based on the condition above, the youth activists conclude and determine to help people themselves. It is the reason why Soetomo has an idea to found an association to unite all Javanese, Sundanese, and Madurese who are willing to concern and help their nation. This society is not the exclusive one and will be open for anyone without considering his or her position, wealth, or education. This idea results in Budi Utomo, May 20, 1908, which is an organinsation / association that aims to achieve something based on the virtue and goodness of a character. This movement is motivated by the deteriorating economic situation in Java Island due to colonial exploitation.

Budi Utomo was declared as the milestone of the beginning of national movement in Indonesia. This organization is engaged in education and social culture at first. The established school named Budi Utomo which has some goals of: trying to maintain and develop Javanese culture through: Advancing teaching, Advancing agriculture, farm, and trade, Advancing engineering and industry, Reliving the culture. Budi Utomo's programs moved quickly enough, therefore, it had successfully established 40 branches in

Journal Homepage:

http://ejournal.undwi.ac.id/index.php/jsds
Magelang, Yogyakarta and Probolinggo with a total membership of 10,000 people by the end 1909. One of Budi Utomo's activities or movements in an effort to advance the education program is to travel around Java offering his idea of forming a study which is called Darma Wara. This movement aims to raise funds to provide scholarships for outstanding students who are not able to continue their studies. An important figure in this organization is Dr. Sutomo, Dr. Cipto Mangunkusumo and Gunawan Mangunkusumo. The establishment of Budi Utomo became the beginning of a national movement which aimed to achieve Indonesian independence.

In the early 1915, Budi Utomo began to move in the political field which was resulted from the background of World War I that prompted the Indian-Dutch government to impose military training for indigenous citizens. This organization became a milestone of the beginning of Indonesia's national movement. Budi Utomo's seffort became the characteristic of the rise of unity and nationalism aswell as awareness spirit to fight the independence of Indonesian. This fact has never appeared during 350 years of colonial era. Budi Utomo (1908) and the Youth Pledge (1928) were the ethical political impacts which had been being fought since the Multatuli period.

\subsubsection{K.H. Dewantara Nationality Thought \\ K.H. Dewantara is an important figure of national hero who has a great contribution to education in Indonesia. The establishment of Taman Siswa College in 1922 was a proof of his awareness which}


has been contributed to the rise of national education. His highly critical and farsighted nationalist thoughts brought himself to be mentioned as Bagawan Pendidikian who belonged to Indonesian Nation. The greatness of his thoughts has raised the dignity of the nation (htt: // national: Sindonews.com senen, 2 May 2016).

Taman Siswa College is an educational institution that provides opportunities for indigenous peoples to get the right of having an education as good as the nobility and the Dutch (https://id.m.wikipedia.org> wiki>). This college emphasizes the education of nationalism to each learner in order to make them love their nation and homeland as well as be able to fight in gaining independence. As a very prolific writer, more than a hundred pieces of his writings have been published with the theme: "Education and Culture which have a concept of Nationalism". Some of his writings lead him to place national education foundation to Indonesian nation. In addition, he has put the conception of education that integrates with the nation cultural traditions. From the beginning, K.H. Dewantara asserted that national teaching should be aligned with the subsistance and life of the nation (Kristyanto in a press release, May 2, 2016).

Fatwas emphasizes that an education should create the determination of mind and soul, to assure self-confidence, and to establish life principle stability. According to K.H. Dewantara, education means the effort to promote the growth of character (soul and character power), mind, and children's bodies. Furthermore, he mentioned that the purpose of education was to guide all the natural forces that exist in the children therefore they can get the highest salvation and happiness as human beings and members of the community (Uno \& Lamatenggo, 2016: 23 \& 27). K. H. Dewantara's date of birth is now commemorated in Indonesia as a National Education Day. Part of his creation motto, tut wuri handayani, became the slogan of the Ministry of Indonesia National Education. Related to his efforts to implement those three fatwas on education, K.H. Dewantara proposed five principles of education which were known as Panca Dharma (nature, freedom, culture, nationality, and humanity).

In 1908, K.H. Dewantara was active in Budi Utomo's propaganda section to socialize and inspire the awareness of Indonesian society about the importance of unity in nation and state. He founded Indische Partij (the first Indonesian political party with Indonesian nationalism) on 25 December 1912 together with Douwes Deker (Dr. Danudirdja Setyabudhi) and dr. Cipto Mangoenkoesumo which aimed to achieve the indepence of Indonesia. These activists and political activities led the term Triassic politic was widely known.

\subsection{Developing The Critical Education}

Uno and Lamatenggo in their book entitled The Foundation of Education (2016 : 7) mentioned that the issue of educational development in Indonesia was only able to provide direct impact that was realized in a certificate. However, it has not given the impact of teaching companion whose indicator was the existence of human
Journal Homepage:

http://ejournal.undwi.ac.id/index.php/jsds
Copyright (C) 2021 Dwijendra University. All right reserved. 
resource competitiveness (HR) to meet the demands of the business world as well as the demands of the industrial world and even the world competition..

There is one thing which should be kept in mind that reflecting and learning from successful educational countries such as Australia, New Zealand, Singapore, South Korea and others are extremely needed; Asian countries will still survive even they are attacked by a crisis storm because of having tough generation to against it. This toughness is a positive impact of the implementation of its national education. Malaysia and Thailand are hit by the crisis along with Indonesia, but both countries can improve themselves slowly and surely due to they have a formidable generation to fight the crisis which results in they are free from all of that until now, while Indonesia is still busy struggling with various crisis and deterioration. Indonesia is reaping the long-term impact of the failure of its education. Uno and Lamatenggo say that there are nine direction mistakes of its educational process which include:

1. Educational success is only measured from the superiority of the cognitive domain.

2. Education / teaching evaluation at schools tends to ignore the convergent thinking patterns.

3. An educational process is transformed into a teaching process.

4. An ability to master the knowledge is not accompanied by a guidance of learning penchant.

5. The titles is becoming an educational target which are not followed by scientific responsibility.

6. Educational materials and textbooks are written with methods to balance theoretical and practical factors, science and technology, faith and piety, educational institutions and working world as well as answer the right-wrong one.

7. Education management does not emphasize the responsibility to all stakeholders.

8. Teacher profession is only impressed to be a scientific profession which is less accompanied by the weight of the humanitarian profession.

9. (All 1-8) were followed by national and multi-dimensional problems (2016: 10).

A strong cultural foundation is needed in order to develop a quality critical education. Educational events are part of the culture of a community or a nation. Therefore, the steps of developing critical education are not free from their culture, or they have to pay attention to socio-cultural factors of society. It is important to pay attention to K. H. Dewantara (1977) opinion in Uno and Lamatenggo (2016: 131) regarding his principle of Trikon to integrate cultural systems within the community or nation which is related to the development of critical education. Those Trikon principles are: (1) Continuity, (2) Convergence, and (3) Concentric. Therefore, the right education for Indonesian nation which has the characteristic of Indonesia is an education
Journal Homepage:

http://ejournal.undwi.ac.id/index.php/jsds
Copyright (C) 2021 Dwijendra University. All right reserved. 
Journal of Sustainable Development Science

Vol. 3, No. 1, June 2021, pp. 9-16

e-ISSN: 2715-9140 | p-ISSN: 2722-919X

that focuses on the nation interest. It means that an education must be able to prepare learners to be able to face the future without abandoning some aspects of intelligence which based on faith and piety toward God Almighty, virtuous noble character, possessing knowledge and skills, physical and spiritual health, a stable and independent personality and responsibility.

According to Adnan, an education which is needed by our nation is an education that is able to: the first one is it has to be able to strengthen the identity of the nation's consciousness; secondly, it should not only emphasize itself on the aspect of intellect and materiality, but also foster spiritual potential; the third one, it must have a vision to strengthen the resilience of a nation's culture that upholds ethics, morals and humanity (Adnan, 1999: 132).

A Critical Education develops fundamental spirit such as : its point of view regarding the core of educational process is not only a knowledge / information transfer, but more than that it is a psychological process or process and practice of culture towards self-awareness. Therefore, selfawareness is becoming the soul and the ultimate goal of education. Therefore, the main method of critical education is strongly dominated by the "dialogicalcritical" principle in its learning process. This approachment aims to develop a critical attitude / awareness as an agent of self-liberation of leraners. According to Freire, this process was called as a cointional activity which is a joint motion among teachers and students to achieve the common goals. In terms of learning, the core of this dialogical-critical process is the combination of "reflection" and "action" motions (see Wija, 2009: 46).

\section{CONCLUSIONS}

If we talk about educational issues which usually tends to focus on the practical dimensions of pedagogic and normative dimensions is certainly not enough to deliver the desire in developing a critical and quality national education. Therefore, the use of one more dimension which is called an ideological cultural dimension needs to be given the same space. Or in other words, the educational process should be formulated properly as a process of cultural dimension. The main key of selfawareness (concientizacao) of every nation is developing a quality education which based on a culture.

Some steps to develop quality critical education in Indonesia have been being seen since the era of R. A. Kartini, Budi Utomo, and K.H. Dewantara. The thought of these nationalism figures are not only succeed in accommodating the realization of national education which can be applied to present, but also shows the world that it can make Indonesia / RI country exists. There are still plenty of problems of education which have not been resolved yet in facing the challenges of rapid and complex global education change. Therefore, it is not only necessary to hold critical dialogs on the national / nationalist ideas of the nation's tough generations, but also the unyielding nationalist movements for the establishment of the Unitary State
Journal Homepage:

http://ejournal.undwi.ac.id/index.php/jsds
Copyright (C) 2021 Dwijendra University. All right reserved. 
Journal of Sustainable Development Science

Vol. 3, No. 1, June 2021, pp. 9-16

e-ISSN: 2715-9140| p-ISSN: 2722-919X

Republic of Indonesia (NKRI). Therefore, Indonesia will be free from the shackles of educational problems that impoverish us all.

\section{REFERENCE}

Arif, Mukhrizaal, dkk., 2016. Pendidikan Posmodernisme Telaah Kritis Pemikiran Tokoh Pendidikan. Yogyakarta: AR. RUZZ MEDIA.

Azra, Azyumardi, 2002. Paradigma Baru Pendidikan Nasional Rekonstruksi dan Demokratisasi. Jakarta: Buku Kompas.

Darmaningtys, 2015, Pendidikan Yang Memiskinkan. Yogyakarta: Intrans Publishing.

Dore, Ronal, 1976. The Diploma Disease: Education Qualifacation and Development. London: Gweworge Allen \& Unwin Ltd.

Freire, Paulo, 1974. Education for Critical Consiousness. New York: Seabury Press.

Lay, Cornelys, 2001. Nasionlisme Etnisitas. Yogyakarta: Dian/Interfidei, Kompas dan Forum Wacana Muda.

Seri Buku Saku Tempo, 2017. Gelap Terang Hidup Kartini.. Jakarta: KPG (Kepustakaan Popular Gramedia) bekerjasama dengan Tempo Publishing.

Singleton John, 1974. Implication of Education as cultural Transmission, dalam George D. Spindler, Education and Cultural Process. New York: Holt Rinehart \& Winston Inc.

Uno, Hamzah B., 2016. Landasan Pendidikan. Jakarta: Bumi Aksara.

Wija, I Gede, 2009. Pendidikan Sebagai Ideologi Budaya. Denpasar: Program Magister (S2) dan Doktor (S3) Kajian Budaya Universitas Udayana bekerjasama dengan Sari Kahyangan Indonesia. 